\title{
Probing GATA factor function in mouse Leydig cells via testicular injection of adenoviral vectors
}

\author{
Gervette M Penny ${ }^{1}$, Rebecca B Cochran¹, Marjut Pihlajoki², Antti Kyrönlahti ${ }^{2}$, Anja Schrade², \\ Merja Häkkinen ${ }^{3}$, Jorma Toppari ${ }^{4}$, Markku Heikinheimo ${ }^{1,2}$ and David B Wilson ${ }^{1,5}$ \\ ${ }^{1}$ Department of Pediatrics, Washington University School of Medicine, St. Louis Children's Hospital, St. Louis, \\ Missouri, USA, ${ }^{2}$ Children's Hospital, University of Helsinki and Helsinki University Hospital, Helsinki, Finland, \\ ${ }^{3}$ University of Eastern Finland, School of Pharmacy, Kuopio, Finland, ${ }^{4}$ Department of Physiology, Institute of \\ Biomedicine, University of Turku and Department of Pediatrics, Turku University Hospital, Turku, Finland and \\ ${ }^{5}$ Department of Developmental Biology, Washington University School of Medicine, St. Louis Children's Hospital, \\ St. Louis, Missouri, USA \\ Correspondence should be addressed to D B Wilson; Email:wilson_d@wustl.edu
}

\begin{abstract}
Testicular Leydig cells produce androgens essential for proper male reproductive development and fertility. Here, we describe a new Leydig cell ablation model based on Cre/Lox recombination of mouse Gata4 and Gata6, two genes implicated in the transcriptional regulation of steroidogenesis. The testicular interstitium of adult Gata $4^{\text {flox/flox}}$; Gata6 ${ }^{\text {flox/flox }}$ mice was injected with adenoviral vectors encoding Cre + GFP (Ad-Cre-IRES-GFP) or GFP alone (Ad-GFP). The vectors efficiently and selectively transduced Leydig cells, as evidenced by GFP reporter expression. Three days after Ad-Cre-IRES-GFP injection, expression of androgen biosynthetic genes (Hsd3b1, Cyp17a1 and Hsd17b3) was reduced, whereas expression of another Leydig cell marker, Ins/3, was unchanged. Six days after Ad-Cre-IRES-GFP treatment, the testicular interstitium was devoid of Leydig cells, and there was a concomitant loss of all Leydig cell markers. Chromatin condensation, nuclear fragmentation, mitochondrial swelling, and other ultrastructural changes were evident in the degenerating Leydig cells. Liquid chromatography-tandem mass spectrometry demonstrated reduced levels of androstenedione and testosterone in testes from mice injected with Ad-Cre-IRES-GFP. Late effects of treatment included testicular atrophy, infertility and the accumulation of lymphoid cells in the testicular interstitium. We conclude that adenoviral-mediated gene delivery is an expeditious way to probe Leydig cell function in vivo. Our findings reinforce the notion that GATA factors are key regulators of steroidogenesis and testicular somatic cell survival.

Free Finnish abstract: A Finnish translation of this abstract is freely available at http://www.reproduction-online.org/content/154/4/455/ suppl/DC2.

Reproduction (2017) 154 455-467
\end{abstract}

\section{Introduction}

Testicular Leydig cells are essential for proper male phenotypic differentiation and fertility (Teerds \& Huhtaniemi 2015). Two distinct populations of Leydig cells arise sequentially during mammalian development (Virtanen \& Toppari 2014). Fetal Leydig cells, which appear soon after testicular organogenesis (E12.5 in the mouse), produce androgens required for masculinization of the fetus $\left(\mathrm{O}^{\prime}\right.$ Shaughnessy \& Fowler 2011, Wen et al. 2016, Shima \& Morohashi 2017). Adult Leydig cells, which arise in the prepubertal period, secrete androgens essential for sexual maturation and spermatogenesis (Teerds \& Huhtaniemi 2015). Both populations of Leydig cells possess the enzymes required for conversion of cholesterol into androstenedione (cholesterol side chain cleavage enzyme (CYP11A1), 3 $\beta$-hydroxysteroid dehydrogenase (HSD3B1) and cytochrome P450 17 $\alpha$-hydroxylase/17,20-lyase (CYP17A1)) (O'Shaughnessy et al. 2002). Adult Leydig cells, but not their fetal counterparts, possess HSD17B3, an enzyme that metabolizes androstenedione into testosterone (O'Shaughnessy et al. 2000, Shima et al. 2013).

Cell-specific ablation models have provided insight into the development and function of Leydig cells (Smith et al. 2015). The most widely used of these models entails administration of ethane dimethane sulfonate (EDS) to adult rats, which triggers the rapid destruction of Leydig cells via apoptosis (Teerds et al. 1989). Three to six weeks after EDS treatment, the adult Leydig cell population regenerates (Kerr et al. 1985, Molenaar et al. 1986). This model has allowed investigators to identify factors that regulate Leydig cell differentiation 
(Molenaar et al. 1986, Yan et al. 2000, Sriraman et al. 2003, Salva et al. 2004, O'Shaughnessy et al. 2008, Zhang et al. 2013, O'Shaughnessy et al. 2014, Lobo et al. 2015, Zhang et al. 2015). Additionally, the EDS model has shed light on stem Leydig cells present in peritubular and perivascular locations within the testicular interstitium (Kilcoyne et al. 2014, Chen et al. 2017). One limitation of EDS is that it does not cause Leydig cell destruction in mice except at high doses that may be associated with additional off-target effects (Smith et al. 2015).

Here, we describe a new Leydig cell ablation model based on delivery of Cre recombinase into the testes of mice harboring floxed alleles of Gata4 and Gata6, two key regulators of steroidogenic cell differentiation and function (Tevosian 2014, Röhrig et al. 2015, Tremblay 2015). Gata4 and Gata6 are expressed in fetal/ adult Leydig cells (Ketola et al. 1999, 2002, MazaudGuittot et al. 2014) and have been shown to activate the promoters of several steroidogenic genes, including Cyp11a1 and Cyp17a1 (Tremblay \& Viger 2001, Jimenez et al. 2003, Rahman et al. 2004, Sher et al. 2007). Conditional targeting of Gata4 in the adrenogonadal primordium and fetal/adult Leydig cells using Sf1-Cre produces undervirilized mice with small testes that lack mature sperm (Manuylov et al. 2011). Simultaneous deletion of both Gata4 and Gata6 using Sf1-cre results in a more severe testicular phenotype marked by a paucity of Leydig cells, reduced testosterone production and the accumulation of adrenal-like cells in the interstitium (Padua et al. 2015). To focus on the function of GATA factors in Leydig cells of the adult mouse, we devised a conditional gene deletion strategy that relies on intratesticular injection of an adenoviral vector encoding Cre. We show that deletion of Gata4+Gata6 in this manner leads to attenuated steroidogenesis followed by destruction of adult Leydig cells. More broadly, our results show that adenoviral-mediated gene delivery is an expeditious and selective means of probing Leydig cell function in vivo.

\section{Materials and methods}

\section{Experimental animals}

Procedures involving mice were approved by the institutional committee for laboratory animal care and were conducted in accordance with the National Research Council's (NRC) publication Guide for Care and Use of Laboratory Animals. Gata4 flox/flox mice (also termed Gata4 ${ }^{\text {tm1.1Sad/J), Gataffloxflox }}$

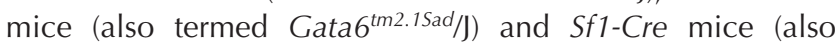
termed FVB- $\operatorname{Tg}(\mathrm{Nr} 5 \mathrm{a} 1$-cre)2Lowl/J) were obtained from the Jackson Laboratory (Bar Harbor, ME, USA) and genotyped as described (Watt et al. 2004, Dhillon et al. 2006, Oka et al. 2006, Sodhi et al. 2006). Gata4 floxfflox mice were crossed with Gata6 $^{\text {flox/flox }}$ mice to produce Gata4 $4^{\text {flox fllox; }}$ Gata6 flox/flox mice. Male Sf1-Crel; Gata4tfloxflox; Gataf $6^{\text {floxfflox }}$ mice were generated using an established breeding scheme (Padua et al. 2015, Tevosian et al. 2015). All mice had free access to water and standard rodent chow and were exposed to 12-h light/12-h darkness photoperiods. At specified times, mice were killed by $\mathrm{CO}_{2}$ asphyxiation.

\section{Intratesticular injection}

We obtained recombinant human adenovirus (serotype 5, dE1/ E3) expressing green fluorescent protein (GFP) alone (Ad-GFP) or in combination with Cre (Ad-Cre-IRES-GFP) from Vector Biolabs (Philadelphia, PA, USA). Male Gata4flox/flox; Gata6 flox/flox mice (2 months old) were anesthetized with a cocktail of ketamine $(100 \mathrm{mg} / \mathrm{kg})$ and xylazine $(10 \mathrm{mg} / \mathrm{kg})$ ip. The intraand post-operative analgesic regimen included buprenorphine $(0.05 \mathrm{mg} / \mathrm{kg} \mathrm{sc})$ and carprofen $(5 \mathrm{mg} / \mathrm{kg} \mathrm{sc})$. We employed two different surgical techniques to inject adenovirus. In initial experiments, an abdominal incision (Qamar et al. 2015) was made to expose the testes for injection. To avoid the potentially confounding variable of surgically induced cryptorchidism, a scrotal incision (Kojima et al. 2003) was made in the subsequent experiments. These alternative methods yielded comparable results, particularly at early time points ( $<7$ days) post injection, indicating that surgical approach was not a major determinant of experimental outcome. Adenovirus $\left(20 \mu \mathrm{L}, 1 \times 10^{7}\right.$ plaque formation units (pfu) per $\mu \mathrm{L}$ in Dulbecco's Modified Eagle's medium (DMEM) containing 2\% BSA and $2.5 \%$ glycerol $(\mathrm{v} / \mathrm{v}))$ was injected slowly into the interstitial space of each testes using a 30-gauge needle. Sham-operated mice underwent skin incision and testes visualization without intratesticular injection.

\section{Histological analyses}

Whole testes or other organs were fixed by overnight immersion in Bouin's solution (Sigma) or 4\% paraformaldehyde (PFA) in PBS. Paraffin-embedded tissue sections $(5 \mu \mathrm{m})$ were stained with hematoxylin and eosin (H\&E) or subjected to immunostaining (Anttonen et al. 2003, Krachulec et al. 2012). The type of fixation and the primary/secondary antibodies used for each antigen are listed in Table 1. Bound antibody was visualized using the avidin-biotin immunoperoxidase system (Vectastain Elite ABC Kit, Vector Laboratories, Inc., Burlingame, CA, USA) and diaminobenzidine. Terminal deoxynucleotidyl transferase dUTP nick end labeling (TUNEL) staining was performed on paraffin-embedded tissue sections using the ApopTag Peroxidase In Situ Apoptosis kit (EMD Millipore). For direct visualization of GFP, cryosections $(10 \mu \mathrm{m})$ were prepared after embedding unfixed testes in O.C.T. compound (Thomas Scientific, Swedesboro, NJ, USA). These sections were mounted in Immu-Mount containing DAPI (ThermoFisher Scientific) and photographed using an Olympus BX60 fluorescence microscope.

\section{Quantitative RT-PCR (RT-qPCR)}

RNA was isolated from whole testes (Kyrönlahti et al. 2011) and subjected to RT-qPCR analysis as described (Dörner et al. 2017), 
Table 1 Tissue fixation methods and antibodies used for immunohistochemistry.

\begin{tabular}{|c|c|c|c|c|}
\hline Antigen & Marker of & Fixative & Primary antibody & Secondary antibody \\
\hline GFP & Adenoviral infection & Bouin's & $\begin{array}{l}\text { ab290, rabbit polyclonal, Abcam, } \\
\text { Cambridge, MA; } 1: 500\end{array}$ & $\begin{array}{l}\text { Goat anti-rabbit biotinylated IgG, NEF-813, } \\
\text { NEN Life Science, Boston, MA; } 1: 2000\end{array}$ \\
\hline GATA4 & $\begin{array}{l}\text { Leydig cells, Sertoli cells, } \\
\text { perivascular cells, some } \\
\text { peritubular cells }\end{array}$ & $4 \%$ PFA in PBS & $\begin{array}{l}\text { sc-1237, goat polyclonal, Santa } \\
\text { Cruz Biotechnology, Santa Cruz, } \\
\text { CA; } 1: 200\end{array}$ & $\begin{array}{l}\text { Donkey anti-goat biotinylated IgG, Jackson } \\
\text { Immunoresearch, West Grove, PA; 1:1000 }\end{array}$ \\
\hline GATA6 & Leydig cells, Sertoli cells & $4 \%$ PFA in PBS & $\begin{array}{l}\text { AF1700, goat polyclonal, R\&D } \\
\text { Systems; } 1: 100)\end{array}$ & $\begin{array}{l}\text { Goat anti-rabbit biotinylated IgG, NEF-813, } \\
\text { NEN Life Science, Boston, MA; 1:2000 }\end{array}$ \\
\hline $\begin{array}{l}\text { Cleaved } \\
\text { caspase-3 }\end{array}$ & Apoptosis & $4 \%$ PFA in PBS & $\begin{array}{l}\text { sc- } 1225 \text {, goat polyclonal, Santa } \\
\text { Cruz Biotechnology, Santa Cruz, } \\
\text { CA; } 1: 200\end{array}$ & $\begin{array}{l}\text { Donkey anti-goat biotinylated IgG, Jackson } \\
\text { Immunoresearch, West Grove, PA; 1:1000 }\end{array}$ \\
\hline $\mathrm{CD} 3 \varepsilon$ & T-lymphocytes & $4 \%$ PFA in PBS & $\begin{array}{l}\text { 145-2C11, hamster monoclonal, } \\
\text { Abcam, Cambridge, MA; 1:500 }\end{array}$ & $\begin{array}{l}\text { Goat anti-hamster biotinylated IgG, BA-9100, } \\
\text { Vector Labs, Burlingame, CA; } 1: 800\end{array}$ \\
\hline CYP17A1 & Leydig cells & Bouin's & $\begin{array}{l}\text { sc-66850, rabbit polyclonal, Santa } \\
\text { Cruz Biotechnology, Santa Cruz, } \\
\text { CA; } 1: 200\end{array}$ & $\begin{array}{l}\text { Goat anti-rabbit biotinylated IgG, NEF-813, } \\
\text { NEN Life Science, Boston, MA; } 1: 2000\end{array}$ \\
\hline $\mathrm{F} 4 / 80$ & Macrophages & $4 \%$ PFA in PBS & $\begin{array}{l}\text { ab16911, rat monoclonal, Abcam, } \\
\text { Cambridge, MA; 1:500 }\end{array}$ & $\begin{array}{l}\text { Goat anti-rat biotinylated IgG, JGR066003, } \\
\text { Accurate Chemical and Scientific Corp., } \\
\text { Westbury, NY; } 1: 800\end{array}$ \\
\hline HSD17B3 & Leydig cells & Bouin's & $\begin{array}{l}\text { sc-135044, rabbit polyclonal, Santa } \\
\text { Cruz Biotechnology, Santa Cruz, } \\
\text { CA; } 1: 200\end{array}$ & $\begin{array}{l}\text { Goat anti-rabbit biotinylated IgG, NEF-813, } \\
\text { NEN Life Science, Boston, MA; } 1: 2000\end{array}$ \\
\hline HSD3B1 & Leydig cells & Bouin's & $\begin{array}{l}\text { sc-30820, goat polyclonal, Santa } \\
\text { Cruz Biotechnology, Santa Cruz, } \\
\text { CA; } 1: 200\end{array}$ & $\begin{array}{l}\text { Donkey anti-goat biotinylated IgG, Jackson } \\
\text { Immunoresearch, West Grove, PA; 1:1000 }\end{array}$ \\
\hline
\end{tabular}

using the primers listed in Table 2. Expression was normalized to the housekeeping genes Gapdh and Actb.

\section{Electron microscopy}

Mice were anesthetized and perfused for $20 \mathrm{~min}$ with modified Karnovsky fixative $(2.5 \%$ glutaraldehyde and $2 \%$ paraformaldehyde in $0.1 \mathrm{M}$ cacodylate buffer) via a needle inserted into the left ventricle (Pihlajoki et al. 2013). Testes were harvested, incubated overnight at $4{ }^{\circ} \mathrm{C}$ in the same fixative, rinsed and then postfixed in $2 \% \mathrm{OsO}_{4}$ for $1 \mathrm{~h}$. The samples were dehydrated and embedded in epoxy resin. Thick sections $(1 \mu \mathrm{m})$ were stained with toluidine blue and examined by light microscopy to determine which blocks were to be thinsectioned. Thin sections were stained with uranyl acetate and lead citrate and photographed using a JEOL 1400 transmission electron microscope.

\section{Liquid chromatography-tandem mass spectrometry (LC-MS/MS)}

Testicular biopsies ( $30 \mathrm{mg}$ each; $n=4$ per group) were harvested and frozen at $-80^{\circ} \mathrm{C}$. Testis tissue was homogenized in $200 \mu \mathrm{L}$ of $0.9 \%$ saline using Precellys beads (KT 039611-003.2, Bertin Technologies, France). Tissue homogenates were spiked with isotope-labeled steroids as internal standards. Samples were then extracted with $1 \mathrm{~mL}$ of toluene (Chromasolv plus for HPLC, Sigma), dried and reconstituted in $30 \%$ acetonitrile. Steroids were measured using an Agilent 1290 Series HPLC system connected to an Agilent 6495

Table 2 Primers for RT-qPCR.

\begin{tabular}{|c|c|c|}
\hline Gene & Oligonucleotide sequence $\left(5^{\prime} \rightarrow 3^{\prime}\right)$ & Reference \\
\hline$A c t b$ & $\begin{array}{l}\text { F: GCGTGACATCAAAGAGAAGC } \\
\text { R: AGGATTCCATACCCAAGAAGG }\end{array}$ & NM_007393.3 \\
\hline Gapdh & $\begin{array}{l}\text { F: GCTCACTGGCATGGCCTTCCGTG } \\
\text { R: TGGAAGAGTGGGAGTTGCTGTTGA }\end{array}$ & NM_008084.2 \\
\hline Cyp11a1 & $\begin{array}{l}\text { F: AGGGGTGGACACGACCTCCA } \\
\text { R: TGCTGGCTTTGAGGAGTGGAACC }\end{array}$ & NM_019779.3 \\
\hline Cyp11b1 & $\begin{array}{l}\text { F: GCTTCACCATGTGCTGAAATCC } \\
\text { R: AGAAGAGAGGGCAATGTGTCA }\end{array}$ & NM_001033229.3 \\
\hline Cyp17a1 & $\begin{array}{l}\text { F: CCAGATGGTGACTCTAGGCCTCTTGTC } \\
\text { R: GGTCTGTATGGTAGTCAGTATCG }\end{array}$ & NM_007809.3 \\
\hline $\ln s / 3$ & $\begin{array}{l}\text { F: CACGCAGCCTGTGGAGACCC } \\
\text { R: CGCTGGCGCTGAGAAGCCT }\end{array}$ & NM_013564.7 \\
\hline Hsd3b1 & $\begin{array}{l}\text { F: TGGACAAAGTATTCCGACCAG } \\
\text { R: GGCACACTTGCTTGAACACAG }\end{array}$ & NM_008293.3 \\
\hline Hsd17b3 & $\begin{array}{l}\text { F: GAGTTGGCCAGACAYGGACT } \\
\text { R: AGCTTCCAGTGGTCCTCTCA }\end{array}$ & NM_008291.3 \\
\hline Sox9 & $\begin{array}{l}\text { F: AGGAAGTCGGTGAAGAACGG } \\
\text { R: GGACCCTGAGATTGCCCAGA }\end{array}$ & NM_011448.4 \\
\hline
\end{tabular}


Triple Quadrupole mass spectrometer. Standard compounds were obtained from Sigma, Steraloids (Newport, RI, USA), Fluka (Bucharest, Romania) and Riedel-de Haën (Seelze, Germany). A publication detailing the analytical method is in preparation.

\section{Assessment of reproductive function}

To assess fertility, male mice that had undergone intratesticular injection with Ad-GFP or Ad-Cre-IRES-GFP were housed continuously with fertility-proven female Gata4 $4^{\text {flox/flox }}$; Gata6 flox/flox mice and the number of offspring documented. Serum luteinizing hormone (LH) levels were measured by ELISA (ERK R7017, Endocrine Technologies; Newark, CA, USA).

\section{Statistical methods}

Steroid, mRNA and LH levels in different groups of mice were compared using the Student's $t$ test. Fertility was compared via two population proportions testing. Statistical significance was set at the following: ${ }^{*} P<0.05$ and ${ }^{* *} P<0.01$.

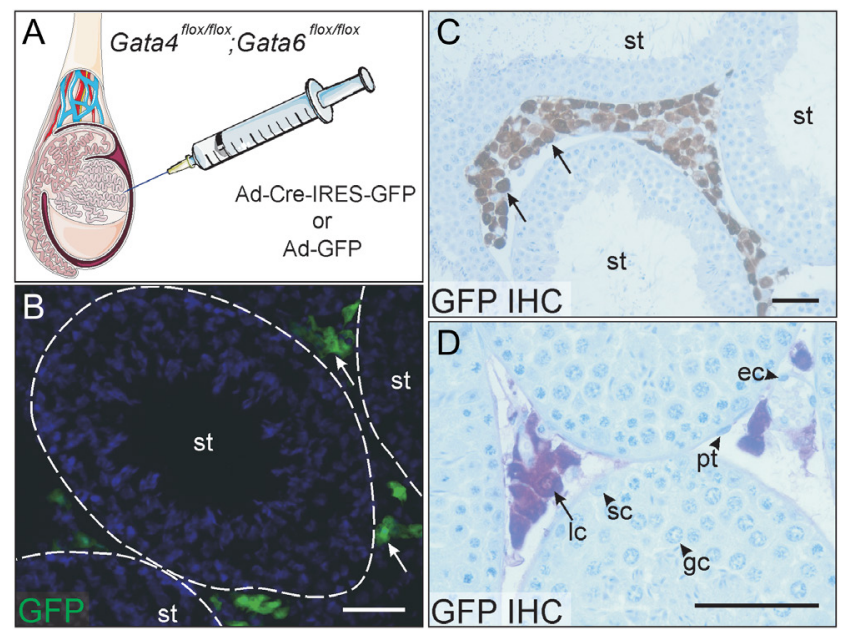

Figure 1 Intratesticular injection of adenovirus results in the selective and efficient transduction of Leydig cells. (A) Adenoviral injection strategy. (B) Two days after injection of Ad-Cre-IRES-GFP, testes were cryosectioned, counterstained with DAPI and examined by fluorescence microscopy. Seminferous tubules are outlined by dashed lines. White arrows highlight $\mathrm{GFP}^{+}$cells in the testicular interstitium. (C and D) Three days after injection of Ad-Cre-IRES-GFP, testes were harvested, fixed in Bouin's solution and subjected to immunoperoxidase staining for GFP. Black arrows in panels C \& D highlight GFP+ Leydig cells. Note that Leydig cells were transduced efficiently, whereas other cell types (endothelial, peritubular, Sertoli and germ cells) were not. Prepared using image vectors from Servier Medical Art (http://smart.servier.com/), licensed under the Creative Commons Attribution 3.0 Unported License (http://creativecommons. org/license/by/3.0/). Ad, adenovirus; ec, endothelial cell; gc, germ cell; GFP, green fluorescent protein; IHC, immunohistochemistry; IRES, internal ribosomal entry site; pt, peritubular cell; sc, Sertoli cell; st, seminiferous tubule. Scale bars $=50 \mu \mathrm{m}$.

\section{Results}

\section{Overview of the adenoviral injection strategy}

The testes of adult Gata4flox/flox; Gatafflox/flox mice were injected with replication incompetent adenoviral vectors encoding Cre + GFP (Ad-Cre-IRES-GFP) or GFP alone (Ad-GFP) (Fig. 1A). We opted to delete Gata4 and Gata6 simultaneously to decrease the chance of a compensatory response and increase the likelihood of a robust phenotype. The dose of virus introduced into each testis was $2 \times 10^{8} \mathrm{pfu}$. Based on an estimate of $3 \times 10^{6}$ Leydig cells per testis (Hu et al. 2010), this dose corresponded to a multiplicity of infection (MOI) of 70 virions per target cell, similar to the $\mathrm{MOI}$ of 100 used previously to transduce primary cultures of mouse Leydig cells (Schrade et al. 2015).

Leydig cells were efficiently transduced by the adenoviral vectors, as evidenced by GFP reporter expression 2-3 days post injection (dpi) (Fig. 1B and C). Moreover, there was uniform expression of the GFP reporter throughout the interstitial compartment, implying adequate dispersion of the small volume $(20 \mu \mathrm{L})$ of injected virus. Other interstitial cell types, such as peritubular cells and vascular cells, were not efficiently transduced (Fig. 1D). There was no GFP expression within the seminiferous tubules, indicating that neither Sertoli cells nor germ cells were infected (Fig. 1B, C and D). Immunostaining of extragonadal organs showed scattered GFP expression in hepatocytes but no appreciable expression of GFP in submaxillary glands, lungs, heart or adrenal glands (data not shown).

\section{Leydig cell ablation in the testes of mice injected with Ad-Cre-IRES-GFP}

The testes of Gata4 $4^{\text {flox/flox }}$; Gata6 $6^{\text {flox/flox }}$ mice were injected with Ad-GFP or Ad-Cre-IRES-GFP and then harvested at varying times for light microscopic analysis. At $3 \mathrm{dpi}$, Leydig cells were evident in both the Ad-GFP- and Ad-Cre-IRES-GFP-treated mice (Fig. 2A and B). Six days after Ad-Cre-IRES-GFP injection, however, the testicular interstitium was depleted of Leydig cells (Fig. 2C and D). Cells remaining in the interstitial compartment of these mice were mainly vascular cells (endothelial cells, smooth muscle cells and pericytes) and resident macrophages (Supplementary Fig. 1A and B, see section on supplementary data given at the end of this article). Leydig cell depletion persisted in the Ad-Cre-IRES-GFPtreated mice at $12 \mathrm{dpi}$ (Fig. 2E and F) and at later time points (see below).

\section{Delayed inflammatory response in the testes of mice injected with adenovirus}

By $12 \mathrm{dpi}$, there was a lymphocytic infiltrate in the testicular interstitium of both the Ad-GFP- and 


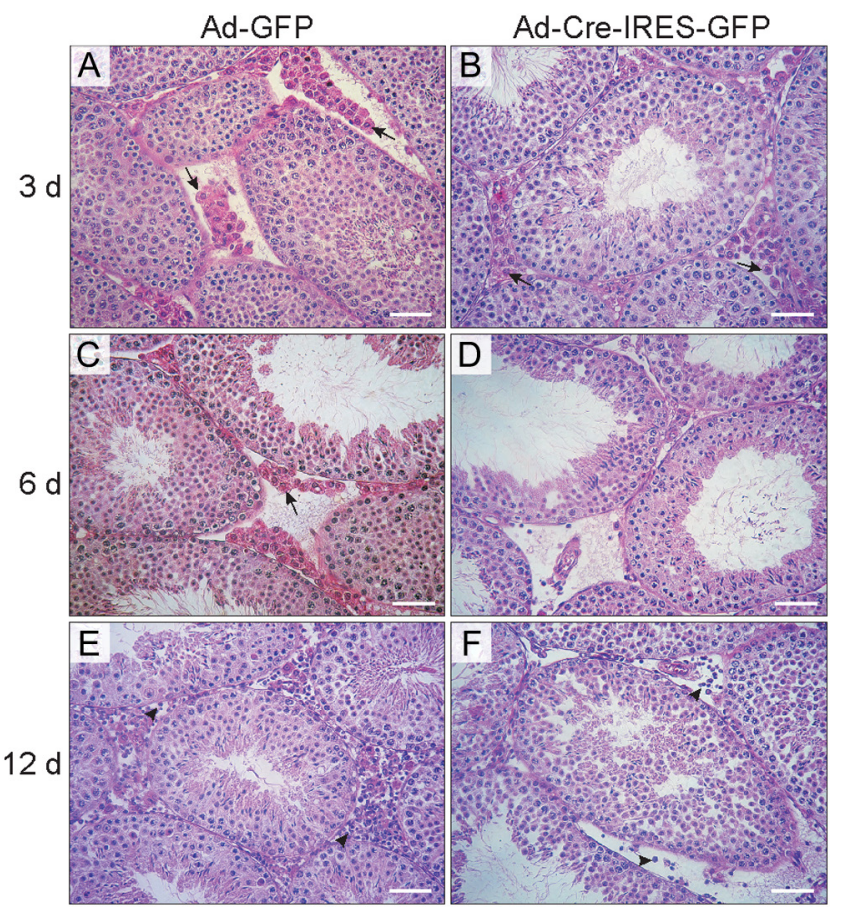

Figure 2 Morphological changes in the testes of Gata4 $4^{\text {flox/flox; }}$ Gata6 flox/flox mice injected with adenoviral vectors. Mouse testes were injected with Ad-GFP (A, C and E) or Ad-Cre-IRES-GFP (B, D and F). Tissue was harvested at the indicated times, fixed in Bouin's solution and stained with H\&E. (A and B) After 3 days, Leydig cells were visible in the testes of mice injected with either Ad-GFP or Ad-CreIRES-GFP (arrows). (C and D) By 6 days, however, the Ad-Cre-IRESGFP-treated testes were devoid of Leydig cells. (E and F) After 12 days, lymphocytes (arrowheads) were evident in the interstitium of both the Ad-GFP- and Ad-Cre-IRES-GFP-injected testes. Scale bars $=50 \mu \mathrm{m}$.

Ad-Cre-IRES-GFP-injected mice (Fig. 2E and F). Immunostaining with CD3 $\varepsilon$ (Fig. 3A, C and E) confirmed that the infiltrating cells were T-lymphocytes. In the testes of mice subjected to sham surgery, there was no evidence of an inflammatory response (data not shown). In mice injected with Ad-GFP, there was a loss of reporter gene expression at $12 \mathrm{dpi}$ that coincided with T-cell infiltration into the testicular interstitium (Fig. 3B, D and F). In addition to curtailing the survival of infected cells, immune cell infiltration may obfuscate the physiological impact of transgene expression (Yang et al. 1994, Blanchard \& Boekelheide 1997). To circumvent the technical limitations imposed by lymphocyte infiltration, we focused the subsequent histological, ultrastructural and biochemical analyses on early time points post infection (days 3-7), when the effects of Cre-Lox recombination on Leydig cell function/survival could be assessed in the absence of overt T-cell infiltration.

\section{Expeditious Cre-mediated recombination in Leydig cells}

To confirm Cre-mediated recombination, testes sections were immunostained for GATA4 and GATA6. Ordinarily,

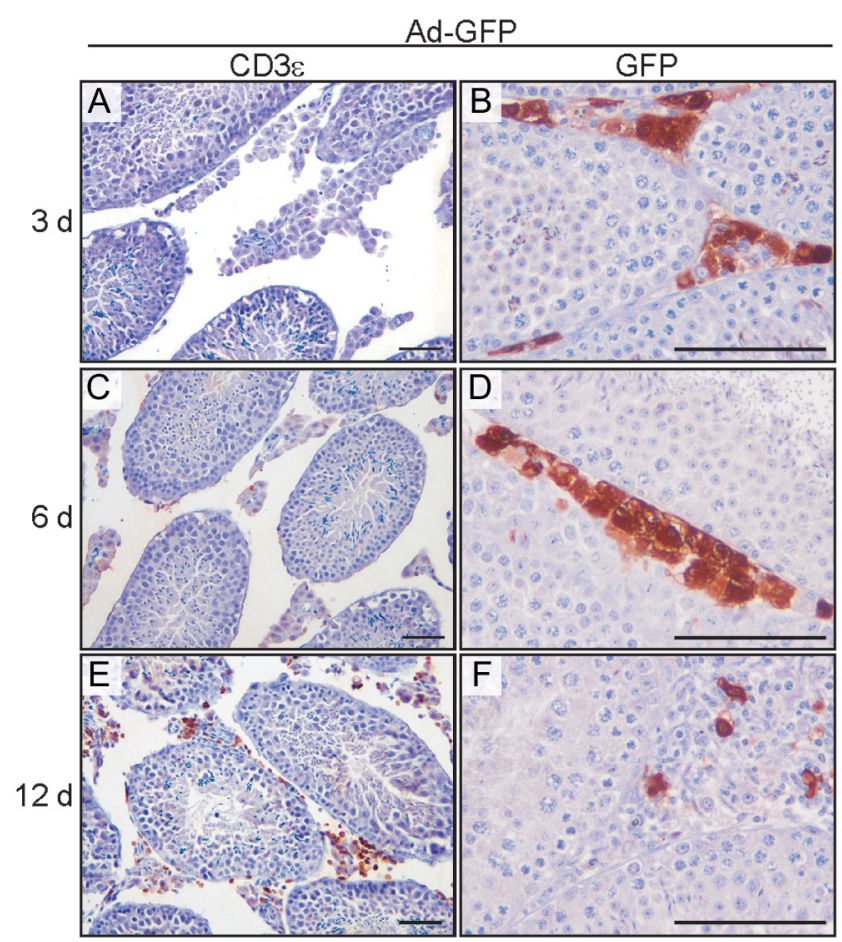

Figure 3 Adenoviral injection triggers the delayed appearance of a T-lymphocytic infiltrate in the testicular interstitium and a concomitant loss of reporter gene expression. The testes of 2-monthold mice were injected with Ad-GFP. Tissue was harvested at the indicated times, fixed in PFA (A, C and E) or Bouin's solution (B, D and $\mathrm{F}$ ) and immunostained for CD3e (A, C and $\mathrm{E})$ or GFP (B, D and F). Note the loss of reporter gene expression at day 12 , coinciding with T-cell infiltration. Scale bars $=50 \mu \mathrm{m}$.

nuclear GATA4 immunoreactivity is evident in Leydig cells, Sertoli cells and some peritubular cells of the adult mouse (Supplementary Fig. 2A) (Viger et al. 1998, Ketola et al. 1999, Bielinska et al. 2007). At 3 dpi, GATA4 was present in Leydig cells of Gata4flox/flox; Gata6 flox/flox mice treated with Ad-GFP but was absent from Leydig cells of mice treated with Ad-Cre-IRES-GFP (Fig. 4A and $B)$, verifying efficient Cre-mediated gene recombination in this cell type. GATA4 staining was preserved in Sertoli cells of mice treated with Ad-Cre-IRES-GFP, underscoring the notion that adenovirus injected into the testicular interstitium selectively infects Leydig cells. At $6 \mathrm{dpi}$, GATA4 ${ }^{+}$Leydig cells were evident in Ad-GFP treated testes but not in Ad-Cre-IRES-GFP-treated testes (Fig. 4C and D). Scattered GATA4 ${ }^{+}$pericytes were observed in the interstitium of the Ad-Cre-IRES-GFP-treated testes (Fig. 4D and Supplementary Fig. 2B). Quantitative analysis of random microscopic fields confirmed a marked reduction in GATA4-immunoreactive interstitial cells in the Ad-Cre-IRES-GFP-treated animals at 3 and 6 dpi $(P<0.01)$ (Supplementary Fig. 3). As with GATA4, staining for GATA6 demonstrated a loss of Leydig cell immunoreactivity in mice injected with Ad-Cre-IRESGFP (Supplementary Fig. 4). 


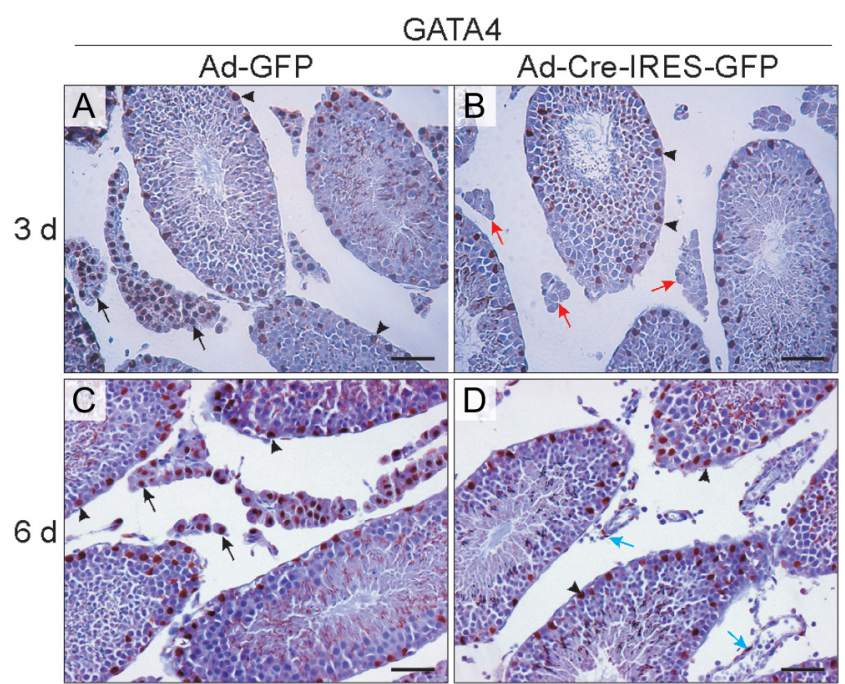

Figure 4 GATA4 immunostaining in the testes of Gatafflox/flox; Gata $^{\text {flox/flox }}$ mice injected with Ad-GFP or Ad-Cre-IRES-GFP. The testes of 2-month-old mice were injected with Ad-GFP (A and C) or Ad-Cre-IRES-GFP (B and D). Tissue was harvested at the indicated times, fixed in PFA and subjected to GATA4 immunoperoxidase staining. (A and B) At 3 days post injection, GATA4 immunoreactivity was evident in Leydig cells of mice injected with Ad-GFP (black arrows) but absent from Leydig cells of mice injected with Ad-CreIRES-GFP (red arrows), confirming efficient Cre-mediated recombination in this cell type. In contrast, GATA4 immunoreactivity was preserved in Sertoli cells (arrowheads). (C and D) At 6 days post injection, GATA4 $4^{+}$Leydig cells were evident in Ad-GFP-treated testes (black arrows) but not in Ad-Cre-IRES-GFP-treated testes. GATA4 ${ }^{+}$ pericytes were observed in the interstitium of the Ad-Cre-IRES-GFPtreated testes (blue arrows). Scale bars $=50 \mu \mathrm{m}$.

\section{Changes in gene expression following Cre-mediated recombination}

We used RT-qPCR to compare the expression of Leydig and Sertoli cell markers in the testes of Gata4 flox/flox; Gataf flox/flox mice injected with Ad-GFP or Ad-CreIRES-GFP (Fig. 5A and B). At 3 dpi, expression of the Leydig cell marker Ins/3 (Anand-Ivell et al. 2009) was comparable in the two groups, confirming the presence of intact Leydig cells. In contrast, at this time point, there was an acute downregulation of androgen biosynthetic genes (Hsd3b1, Cyp17a1, Hsd17b3) in mice treated with Ad-Cre-IRES-GFP $(P<0.01)$. By $7 \mathrm{dpi}$, all Leydig cell markers examined (Ins/3, Cyp11a1, Hsd3b1, Cyp17a1, Hsd17b3) were markedly attenuated $(P<0.01)$ in the mice injected with Ad-Cre-IRES-GFP, consistent with ablation of this cell type. Expression of Sox9, a Sertoli cell marker, was unchanged at 3 and $7 \mathrm{dpi}$, reinforcing the premise that Ad-Cre-IRES-GFP injection selectively affects the interstitial compartment.

To validate the RT-qPCR findings, we performed immunohistochemistry for HSD3B1, CYP17A1 and HSD17B3 (Fig. 6). Six days after injection of Ad-CreIRES-GFP, immunoreactivity for these steroidogenic enzymes was reduced, consistent with a loss of Leydig cells.
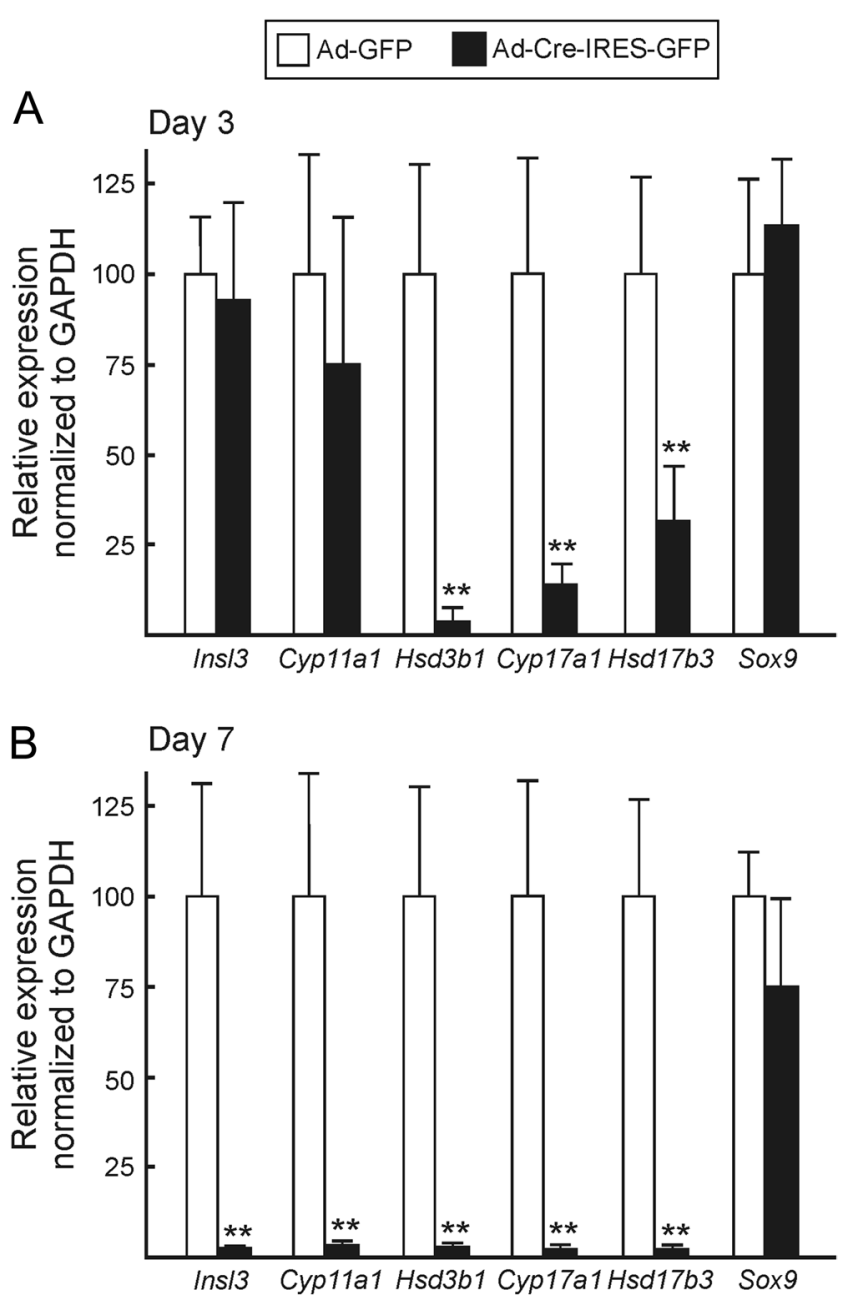

Figure 5 RT-qPCR analysis of testes from Gata4 $4^{\text {flox/flox; }}$ Gata6 $6^{\text {flox/flox }}$ mice injected with Ad-GFP or Ad-Cre-IRES-GFP. The testes of 2-month-old mice were injected with Ad-GFP or Ad-Cre-IRES-GFP. At 3 days (A) or 7 days (B) post-infection, RNA was extracted from whole testis and subjected to RT-qPCR. Results were normalized to expression of the housekeeping gene Gapdh. Normalization to Actb expression yielded similar results. Values are expressed as the mean \pm S.D. $\left(n=4\right.$ per group; $\left.{ }^{* *} P<0.01\right)$.

\section{Ultrastructural and biochemical analysis of cell death in mice injected with Ad-Cre-IRES-GFP}

To gain insights into the process of Leydig cell death in the adenovirus injection model, resin-embedded tissue was processed for light microscopy (Supplementary Fig. 5) and transmission electron microscopy (Fig. 7A, B, C and D and Supplementary Fig. 6). Vacuole-laden activated macrophages, harbingers of Leydig cell death, were prominent in the testicular interstitium of mice treated 4 days earlier with Ad-Cre-IRES-GFP. Leydig cells exposed to Ad-Cre-IRES-GFP, but not Ad-GFP, contained clumps of condensed chromatin beneath the nuclear membrane. Nuclear fragmentation was evident in some of these Leydig cells. Cytoplasmic organelles in Ad-Cre-IRES-GFP-treated Leydig cells had changes not seen in their Ad-GFP-treated counterparts, 


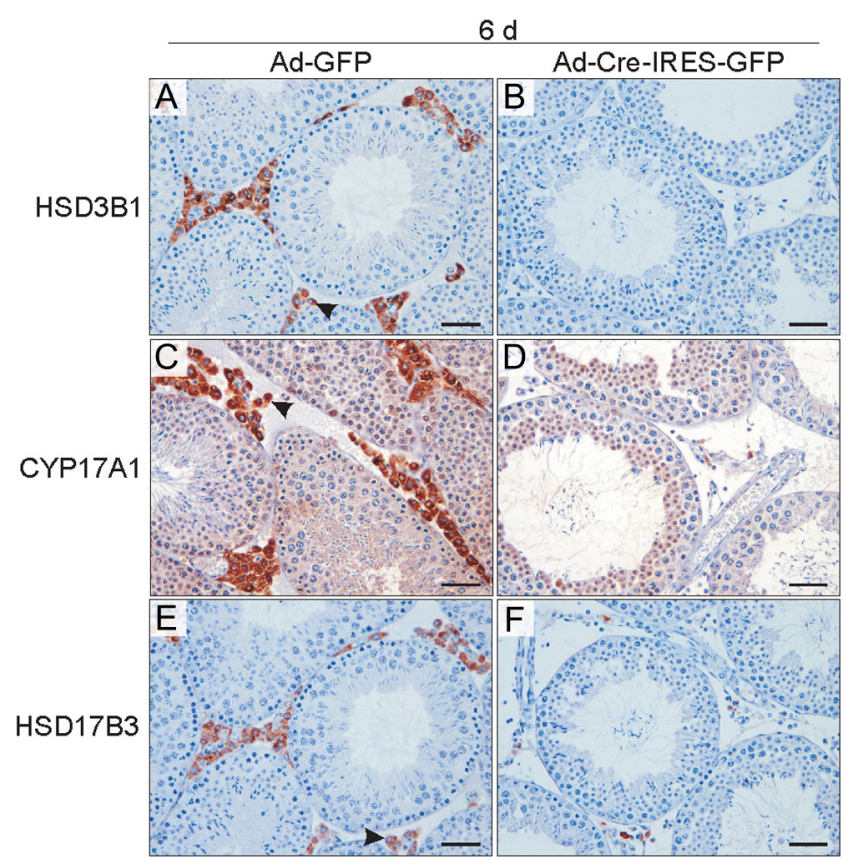

Figure 6 Immunostaining for steroidogenic enzymes in the testes of Gata4 $4^{\text {flox/flox; }}$ Gata6 $6^{\text {flox/flox }}$ mice injected with Ad-GFP or Ad-Cre-IRESGFP. The testes of 2-month-old mice were injected with Ad-GFP (A, C and E) or Ad-Cre-IRES-GFP (B, D and F). Tissue was harvested 6 days later, fixed in Bouin's solution and subjected to immunostaining for HSD3B1 (A and B), CYP17A1 (C and D) or HSD17B3 (E and F). Bars $=50 \mu \mathrm{m}$.

such as mitochondrial swelling, loss of definition of mitochondrial cristae and enlargement of lipid droplets. Some of these degenerative changes were suggestive of apoptosis (Jackson et al. 1986, Gao et al. 2002), but other forms of cell death (e.g., necroptosis, ferroptosis) could not be excluded based on ultrastructural analysis alone.

Looking for biochemical evidence of Leydig cell apoptosis, we performed immunostaining for cleaved (activated) caspase-3 and TUNEL staining. Compared to sham-operated mice, there was no increase in cleaved caspase-3 immunoreactivity in the Ad-GFP or Ad-Cre-IRES-GFP mice $3 \mathrm{dpi}$ (data not shown). Similarly, there was no evidence of increased TUNEL staining in either the Ad-GFP or the Ad-Cre-IRES-GFP mice 3 or 6 dpi (data not shown). Thus, the mechanistic basis of Leydig cell death in the Ad-Cre-IRES-GFP mice remains uncertain.

\section{Reduced androgen levels in the testes of mice injected with Ad-Cre-IRES-GFP}

We used LC-MS/MS to quantify steroids in testis homogenates from Gata4tlox/flox; Gata6flox/flox mice treated 7 days earlier with Ad-GFP or Ad-Cre-IRES-GFP (Fig. 8). Testes from mice injected with Ad-Cre-IRES-GFP had reduced levels of androstenedione $(P<0.01)$ and testosterone $(P<0.05)$. On the other hand, there was no difference in the levels of intratesticular corticosterone in mice injected with Ad-GFP vs Ad-Cre-IRES-GFP $(41 \pm 14 \mathrm{pmol} / \mathrm{g}$ vs $31 \pm 17 \mathrm{pmol} / \mathrm{g}$, $P=0.4)$.

\section{Late effects of adenovirus-mediated gene targeting}

In contrast to EDS-induced ablation/regeneration in the rat, there was slow and variable Leydig cell regeneration in the testes of Gata4 flox/flox; Gata6 flox/flox mice treated with Ad-Cre-IRES-GFP. By $~ 30 \mathrm{dpi}$, much of the testicular interstitium remained devoid of Leydig cells (Fig. 9A). Residual Leydig cells clustered in small patches, and
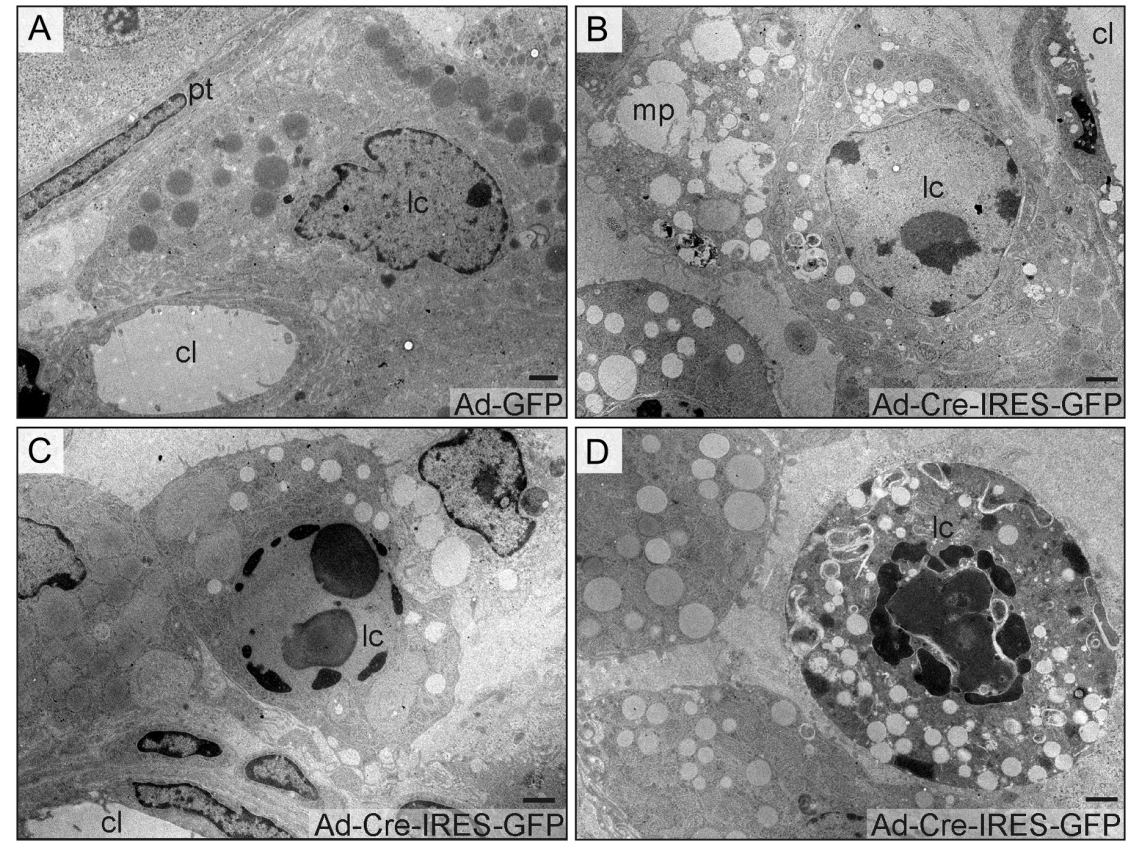

Figure 7 Degenerative changes in Leydig cells of Gata4 $4^{\text {flox }}$ flox; Gata6 $6^{\text {flox/flox }}$ mice injected with Ad-Cre-IRES-GFP. The testes of 2-month-old mice were injected with Ad-GFP (A) or Ad-Cre-IRES-GFP (B-D). Tissue was harvested 4 days later and analyzed by transmission electron microscopy. (A) Normal Leydig cell with a thin rim of heterochromatin beneath the nuclear membrane. (B) Leydig cell with patches of condensed chromatin; adjacent is an activated macrophage with filopodia and large vacuoles containing cellular debris. (C) Leydig cell with prominent chromatin condensation. (D) Leydig cell exhibiting nuclear fragmentation. cl, capillary lumen; lc, Leydig cell; mp, macrophage; pt, peritubular cell. Scale bars $=1 \mu \mathrm{m}$. 

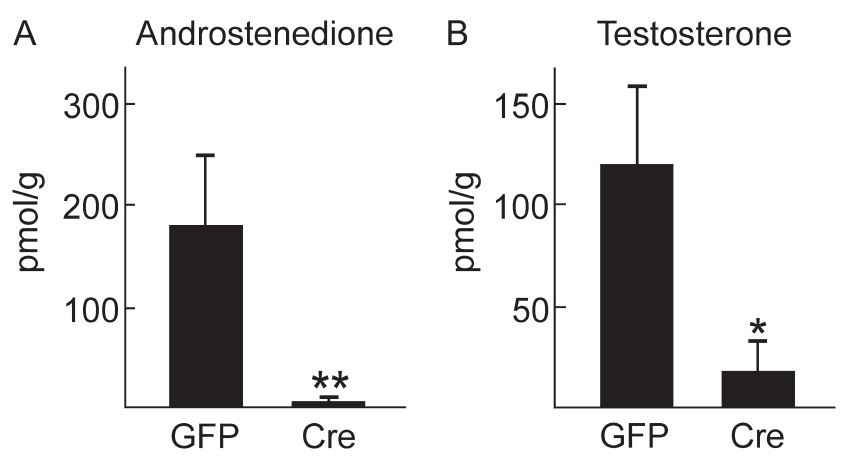

Figure 8 Steroid hormone levels in testis homogenates from Gata ${ }^{\text {flox/flox }}$; Gata6 flox/flox mice injected with Ad-GFP or Ad-Cre-IRESGFP. Ad-GFP ('GFP') or Ad-Cre-IRES-GFP ('Cre') was injected into the testes of 2-month-old Gata4 $4^{\text {flox/flox }}$; Gata6 flox/flox mice. Tissue was harvested 7 days later. Testis homogenates were extracted and subjected to LC-MS/MS to determine the concentrations of (A) androstenedione and (B) testosterone. Values are expressed as pmol steroid per $g$ of testis (mean \pm S.D.; ${ }^{*} P<0.05 ;{ }^{*} P<0.01 ; n=4$ per group).

all were GATA4 ${ }^{+}$suggesting that these cells or their stem cell progenitors escaped adenovirus-mediated Cre inactivation (Fig. 9B). Some of these Leydig cells appeared cytomegalic (Fig. 9B), perhaps reflecting a compensatory response to impaired regeneration. Between 30 and $120 \mathrm{dpi}$, the number of Leydig cells (all of which were GATA4 ${ }^{+}$) increased (Fig. 9C, D, E and $\mathrm{F}$ ), although there was mouse-to-mouse variability in the extent of Leydig cell regeneration. Underscoring the inconsistency in Leydig cell recovery, serum LH values at $90-92 \mathrm{dpi}$ ranged from 0.6 to $32 \mathrm{ng} / \mathrm{mL}$ (mean $=11 \mathrm{ng} / \mathrm{mL}, n=4)$, whereas serum LH values for age-matched sham controls were consistently low (mean $=0.5 \pm 0.2 \mathrm{ng} / \mathrm{mL}, n=5$ ). By $\sim 90 \mathrm{dpi}$, patches of lymphoid cells were evident in the testicular interstitium of mice treated with Ad-Cre-IRES-GFP (Fig. 9C, D, E and F). The void created by Leydig cell ablation may have permitted the accumulation of these lymphoid patches, which were as large as $1 \mathrm{~mm}$ in diameter. Neither the variable Leydig cell regeneration nor the accumulation of lymphoid aggregates was attributable to impaired clearance of virus, as there was no evidence of persistent GFP immunoreactivity between 30 and 90 dpi (data not shown). In the months following Ad-Cre-IRES-GFP injection, changes were seen in the seminiferous epithelium (e.g., thinning, vacuolization, absence of mature sperm), consistent with inadequate androgen production (Fig. 9C, D, E and F and data not shown). Testicular atrophy was evident in some of the older Ad-Cre-IRES-GFP-injected mice, likely reflecting impaired spermatogenesis (Fig. 9G). When Gata4tlox/flox; Gata6 flox/flox mice treated with Ad-Cre-IRES-GFP $(n=5)$ were housed for 3 months with fertility-proven wild-type females, no progeny were observed. By comparison, 3 of 4 Gata4 flox/flox; Gata6 flox/flox mice injected with Ad-GFPsired pups in the months following injection $(P<0.05)$.
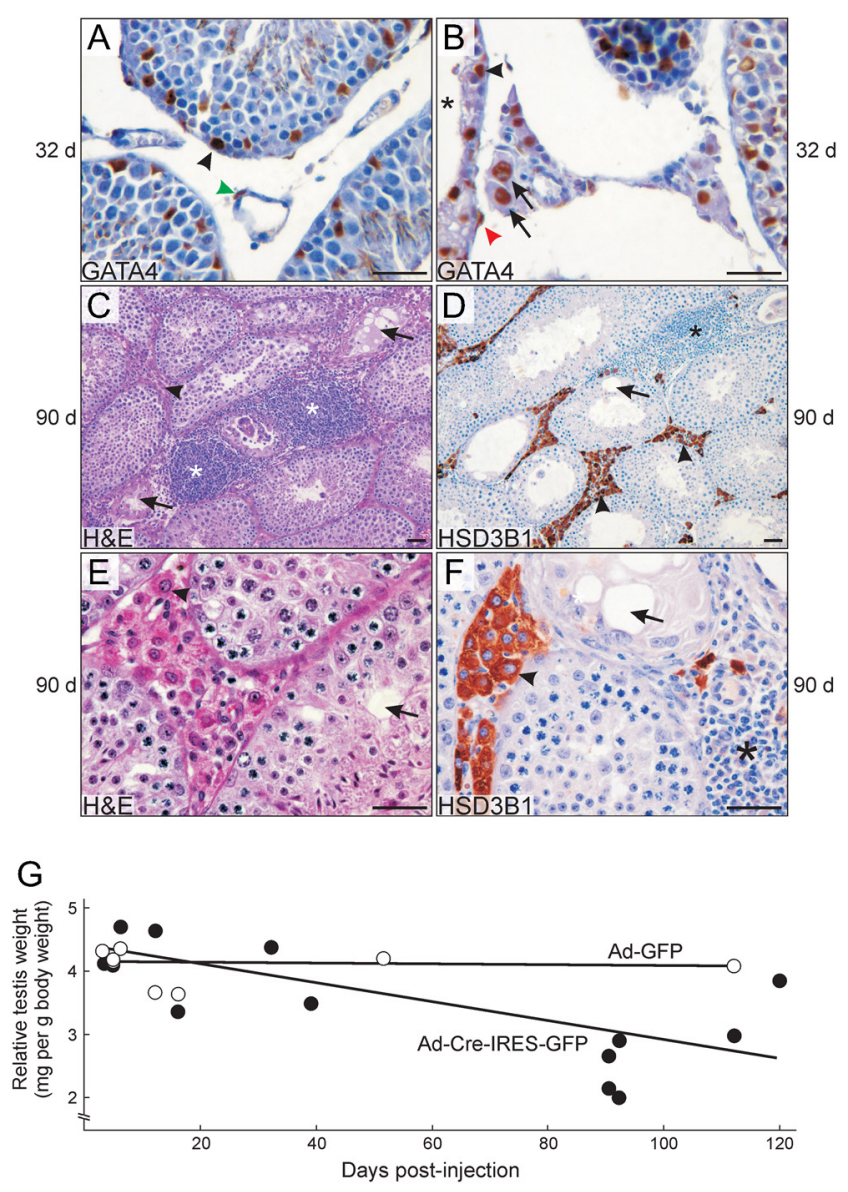

Figure 9 Late changes in testicular histology and weight following injection of Ad-Cre-IRES-GFP into Gata4 $4^{\text {flox/flox}}$; Gata6 $6^{\text {flox/flox }}$ mice. (A and B) GATA4 immunostaining of PFA-fixed testis from a mouse injected 1 month earlier with Ad-Cre-IRES-GFP. As shown in panel A, most of the testicular interstitial space lacked Leydig cells. Panel B shows a rare patch of Leydig cells that are GATA4 immunoreactive, suggesting that they or their progenitors escaped Cre inactivation. Some of these Leydig cells exhibited cytomegaly (black arrows). Other $\mathrm{GATA}^{+}$cell types seen are Sertoli cells (black arrowheads), pericytes (green arrowhead) and peritubular cells (red arrowhead). The asterisk indicates a seminferous tubule with thin epithelium. (C, D, E and F) $\mathrm{H} \& \mathrm{E}$ staining and HSD3B1 immunostaining of Bouin's-fixed testis from mice injected 3 months earlier with Ad-Cre-IRES-GFP.

Arrowheads highlight Leydig cells. Arrows indicate seminiferous tubule degeneration. Asterisks highlight lymphoid aggregates. (G) The testes of 2-month-old mice were injected with Ad-GFP (open circle) or Ad-Cre-IRES-GFP (closed circle). At the indicated times, testes were harvested and weighed. Data points represent the average of two testes per mouse. There was no statistical difference between the slopes of the curves $(P=0.4)$. Scale bars $=25 \mu \mathrm{m}$.

Tevosian and coworkers have shown that male Sf1cre; Gata4flox/flox; Gata6 flox/flox mice survive congenital adrenocortical aplasia due to production of corticoids by adrenal-like cells that accumulate in the testes postnatally (Padua et al. 2015, Tevosian et al. 2015). These heterotopic cells express adrenocortical markers (Cyp21a1, Cyp11b1, Cyp11b2 and Mc2r). To test whether adrenal-like cells arise in the testes of 


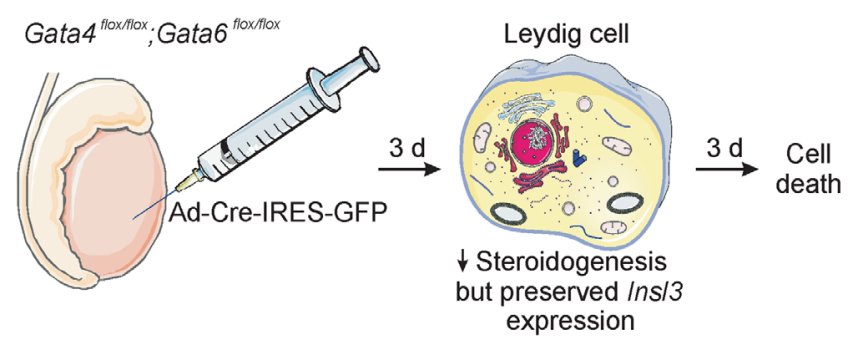

\begin{tabular}{|c|c|}
\hline Advantages & Disadvantages \\
\hline Leydig cell-specific & $\begin{array}{c}\text { Lymphocytic infiltrate limits } \\
\text { analysis at later time points }\end{array}$ \\
\hline $\begin{array}{c}\text { Efficient and temporally } \\
\text { controllable }\end{array}$ & $\begin{array}{c}\text { Incomplete Leydig cell } \\
\text { regeneration }\end{array}$ \\
\hline
\end{tabular}

Figure 10 Salient features of the adult Leydig cell ablation model. Injection of Ad-Cre-IRES-GFP into the testicular interstitium of adult mice resulted in the selective transduction of Leydig cells. At 3 days post infection, there was decreased transcription of steroidogenic enzyme genes, but expression of Ins/3, another Leydig cell marker, was unchanged. By 6 days post infection, there was Leydig cell destruction. Prepared using image vectors from Servier Medical Art (http://smart.servier.com/), licensed under the Creative Commons Attribution 3.0 Unported License (http://creativecommons.org/ license/by/3.0/).

Gata4 flox/flox; Gata6 flox/flox mice injected with Ad-CreIRES-GFP, we performed RT-qPCR analysis for adrenal markers. In contrast to the testes of Sf1-cre; Gata4tlox/flox; Gata flox/flox mice (which were included in the analysis as positive controls), there was no upregulation of adrenal markers in the testes of Gata4 flox/flox; Gata6 flox/flox mice that had been injected 90 days earlier with Ad-Cre-IRESGFP vs Ad-GFP (data not shown).

\section{Discussion}

Cell-specific ablation models have proven invaluable for the analysis of Leydig cell differentiation and function (Smith et al. 2015). We have developed a new Leydig cell ablation model, the features of which are summarized in Fig. 10. Our approach relies on adenoviral-mediated delivery of Cre recombinase into the testicular interstitium of mice harboring floxed alleles of Gata4 and Gata6. This method of gene delivery has inherent advantages for the study of Leydig cells. As shown here and elsewhere (Blanchard \& Boekelheide 1997, Hall et al. 2000, Kojima et al. 2003, LeCouter et al. 2003, Shiraishi \& Ascoli 2007, Qamar et al. 2009, Qamar et al. 2015, Schrade et al. 2015), adenovirus efficiently transduces Leydig cells in vitro and in vivo. Moreover, adenovirus injected into the testicular interstitium selectively infects Leydig cells, thereby minimizing off-target effects. Adenoviral vectors rarely integrate into host chromosomes (0.001$1 \%$ of infected cells), so Leydig cell gene expression is not subject to viral DNA integration effects (Mitani \& Kubo 2002). Recombinant adenovirus has been used to drive the expression of not only Cre but also small hairpin RNAs (shRNAs) (Machitani et al. 2013). Such adenoviral shRNA constructs could be used to silence genes in the Leydig cells of mice lacking floxed alleles. Thus, our adenoviral delivery method could be adapted to study the roles of other genes implicated in Leydig cell function.

The principal shortcoming of adenoviral gene delivery is that it triggers an immune response in the testis and other organs (Blanchard \& Boekelheide 1997, Hendrickx et al. 2014, Tsuzuki et al. 2016). In the liver, where this response has been characterized in detail, adenoviral transduction stimulates a lymphocytic infiltrate that leads to destruction of genetically modified cells and repopulation with hepatocytes lacking the transgene (Yang et al. 1994). This immune response is directed against de novo-synthesized viral components and is independent of MOI (Yang et al. 1994). In the liver and other cell types, the lymphocytic infiltrate typically appears $\sim 10$ days post infection and resolves $\sim 30$ days post infection, coinciding with a loss of transgene expression (Yang et al. 1994, Blanchard \& Boekelheide 1997). We circumvented this limitation of the adenoviral delivery system by focusing on changes in Leydig cell gene expression, function and survival at early time points $(<7$ days) post infection, before the appearance of a pronounced T-lymphocytic infiltrate. Another limitation of the adenoviral injection method is its relative irreversibility. The method apparently kills a significant fraction of Leydig cell precursors, although some escape Cre-mediated recombination and partially repopulate the interstitium after several weeks. Inflammation may accentuate the adverse effects of adenoviral-mediated gene targeting.

The interstitial injection technique described here complements other methods for delivering transgenes or inhibitory RNAs to specific testicular cell populations in rodents. Retrograde instillation of adenoviral vectors into efferent ductules can transduce cells within the seminiferous tubules (Blanchard \& Boekelheide 1997, Kanatsu-Shinohara et al. 2002, Kojima et al. 2003, Hooley et al. 2009). Injection of retrovirus (KanatsuShinohara et al. 2004) or lentivirus (Ikawa et al. 2002, Kim et al. 2010) into the testis results in infection of multiple cell types including germ cells, Sertoli cells and/or Leydig cells. Direct testicular injection of a buffered salt solution can be used to introduce shRNA into germ cells, albeit with low transfection efficiency $(<5 \%)$ (Ho et al. 2017). Early gonadal development can be disrupted by cultivating organs in hanging droplets of media supplemented with vivo-morpholinos (Rudigier et al. 2017). Cre can be targeted to mouse Leydig cells by germline transmission of transgenes, such as Sf1-Cre (Bingham et al. 2006), CYP11A1-iCre (Wu et al. 2007) and Cyp17a1-iCre (Bridges et al. 2008). Although germline Cre transgenes avoid the problem of virus-induced host immunity, generation 
of such mouse mutants is time consuming, and interpretation of the resultant testicular phenotypes may be challenging because of context-dependent effects, variable degrees of Cre-mediated recombination, compensatory responses, alternative pathways of differentiation and functional redundancy (Smith 2011, Tevosian 2014). Adenoviral delivery of Cre or shRNA affords a means of probing the in vivo function of a gene in Leydig cells before committing to germline transmission of a Leydig cell-specific Cre transgene. Intratesticular injection of adenovirus also can be used to study the short-term impact of overexpression of a gene in Leydig cells. For instance, LeCouter et al. (2003) used interstitial injection of adenoviral vectors to drive the expression of angiogenic peptides in mouse testis; histological changes characteristic of angiogenesis were evident $7 \mathrm{dpi}$.

In vitro studies have provided genetic evidence that GATA factors regulate steroidogenesis in Leydig cells. For example, silencing of Gata4 in Leydig tumor cell lines (MA-10, mLTC-1) and primary adult Leydig cells has been shown to impair the expression of androgen biosynthetic genes (Cyp11a1, Hsd3b1, Cyp17a1) (Bergeron et al. 2015, Schrade et al. 2015). In keeping with these prior reports, we found that adenovirusmediated deletion of Gata4/6 in adult Leydig cells caused the acute downregulation of genes involved in sex steroid production, whereas expression of another Leydig cell marker, Ins/3, was preserved at early time points. An advantage of our in vivo model over cell culture-based systems is that the functional changes observed in response to conditional gene targeting occur in a more physiologic milieu of endocrine and paracrine factors (e.g., LH).

In our model of adenoviral-mediated targeting of Gata4/6, we found that the acute decline in testicular steroidogenesis was followed days later by Leydig cell death. This finding is reminiscent of a study in which treatment of MA-10 cells with an apoptosis-inducing agent caused a decrease in steroid production in advance to cell death (King et al. 1998). GATA4 has been shown to enhance cell survival and/or decrease apoptosis in Leydig cell lines and other steroidogenic cell types (Bennett et al. 2013, Anttonen et al. 2014, Schrade et al. 2015, Pihlajoki et al. 2016). The precise mechanism of cell death in our model remains unclear. Ultrastructural analysis of Ad-Cre-IRES-GFP-treated Leydig cells demonstrated organelle changes compatible with apoptosis and other forms of cell death. In the rat EDS model, Leydig cells undergo apoptosis. This process is mediated by caspase- 3 activation (Kim et al. 2000) but does not involve Bcl-2 family members (Taylor et al. 1998); instead, EDS appears to act through activation of Fas (Taylor et al. 1999) and other pro-apoptotic factors (Li et al. 2012). We found no immunohistological evidence of caspase-3 activation in our model, and TUNEL staining was negative. In cultured gonadal somatic cell lines, silencing of Gata4 impairs glycolysis and causes other metabolic derangements (Schrade et al. 2015, Schrade et al. 2016). Thus, it is conceivable that altered metabolism contributes to Leydig cell death in our adenoviral injection model.

Gata4 is expressed in not only fetal/adult Leydig cells but also in putative stem Leydig cells (Kilcoyne et al. 2014). Circumstantial evidence supports a role for GATA4 in the differentiation of Leydig stem/progenitor cells. For example, enforced expression of Gata4 plus two other transcription factors (Sf1 and Dmrt1) can reprogram mouse fibroblasts into Leydig-like cells (Yang et al. 2017). GATA6, like GATA4, has been implicated in mesenchymal stem cell function (Almalki \& Agrawal 2016). The incomplete regeneration of Leydig cells that typifies our adenoviral injection model could reflect, at least partly, impaired Leydig stem cell function, and future experiments will explore this possibility.

\section{Supplementary data}

This is linked to the online version of the paper at http://dx.doi. org/10.1530/REP-17-0311.

\section{Declaration of interest}

The authors declare that there is no conflict of interest that could be perceived as prejudicing the impartiality of the research reported.

\section{Funding}

This work was supported by DOD grants PC141008 and OC150105, the Prostate Cancer Foundation, NIH grant DK52574, the Sigrid Jusélius Foundation and the Academy of Finland.

\section{Acknowledgments}

The authors thank members of the histology and electron microscopy cores for technical assistance, Celeste Morley and Betsy Todd for providing reagents, Ronni M Götz for assistance with pilot studies and Ida Qin for statistical analysis.

\section{References}

Almalki SG \& Agrawal DK 2016 Key transcription factors in the differentiation of mesenchymal stem cells. Differentiation 92 41-51. (doi:10.1016/j.diff.2016.02.005)

Anand-Ivell R, Heng K, Hafen B, Setchell B \& Ivell R 2009 Dynamics of INSL3 peptide expression in the rodent testis. Biology of Reproduction 81 480-487. (doi:10.1095/biolreprod.109.077552)

Anttonen M, Ketola I, Parviainen H, Pusa AK \& Heikinheimo M 2003 FOG-2 and GATA-4 are coexpressed in the mouse ovary and can modulate Müllerian-inhibiting substance expression. Biology of Reproduction 68 1333-1340. (doi:10.1095/biolreprod.102.008599)

Anttonen M, Pihlajoki M, Andersson N, Georges A, L'Hote D, Vattulainen S, Färkkilä A, Unkila-Kallio L, Veitia RA \& Heikinheimo M 2014 FOXL2, 
GATA4, and SMAD3 co-operatively modulate gene expression, cell viability and apoptosis in ovarian granulosa cell tumor cells. PLOS ONE 9 e85545. (doi:10.1371/journal.pone.0085545)

Bennett J, Baumgarten SC \& Stocco C 2013 GATA4 and GATA6 silencing in ovarian granulosa cells affects levels of mRNAs involved in steroidogenesis, extracellular structure organization, IGF-I activity, and apoptosis. Endocrinology 154 4845-4858. (doi:10.1210/en.2013-1410)

Bergeron F, Nadeau G \& Viger RS 2015 GATA4 knockdown in MA-10 Leydig cells identifies multiple target genes in the steroidogenic pathway. Reproduction 149 245-257. (doi:10.1530/REP-14-0369)

Bielinska M, Seehra A, Toppari J, Heikinheimo M \& Wilson DB 2007 GATA-4 is required for sex steroidogenic cell development in the fetal mouse. Developmental Dynamics 236 203-213. (doi:10.1002/dvdy.21004)

Bingham NC, Verma-Kurvari S, Parada LF \& Parker KL 2006 Development of a steroidogenic factor 1/Cre transgenic mouse line. Genesis $\mathbf{4 4}$ 419-424. (doi:10.1002/dvg.20231)

Blanchard KT \& Boekelheide K 1997 Adenovirus-mediated gene transfer to rat testis in vivo. Biology of Reproduction 56 495-500. (doi:10.1095/ biolreprod56.2.495)

Bridges PJ, Koo Y, Kang DW, Hudgins-Spivey S, Lan ZJ, Xu X, DeMayo F, Cooney A \& Ko C 2008 Generation of Cyp17iCre transgenic mice and their application to conditionally delete estrogen receptor alpha (Esr1) from the ovary and testis. Genesis 46 499-505. (doi:10.1002/dvg.20428)

Chen H, Wang Y, Ge R \& Zirkin BR 2017 Leydig cell stem cells: identification, proliferation and differentiation. Molecular and Cellular Endocrinology 445 65-73. (doi:10.1016/j.mce.2016.10.010)

Dhillon H, Zigman JM, Ye C, Lee CE, McGovern RA, Tang V, Kenny CD, Christiansen LM, White RD, Edelstein EA et al. 2006 Leptin directly activates SF1 neurons in the VMH, and this action by leptin is required for normal body-weight homeostasis. Neuron 49 191-203. (doi:10.1016/j. neuron.2005.12.021)

Dörner J, Martinez Rodriguez V, Ziegler R, Rohrig T, Cochran RS, Götz RM, Levin MD, Pihlajoki M, Heikinheimo M \& Wilson DB 2017 GLI1+ progenitor cells in the adrenal capsule of the adult mouse give rise to heterotopic gonadal-like tissue. Molecular and Cellular Endocrinology 441 164-175. (doi:10.1016/j.mce.2016.08.043)

Gao HB, Tong MH, Hu YQ, Guo QS, Ge R \& Hardy MP 2002 Glucocorticoid induces apoptosis in rat leydig cells. Endocrinology 143 130-138. (doi:10.1210/endo.143.1.8604)

Hall SJ, Bar-Chama N, Ta S \& Gordon JW 2000 Direct exposure of mouse spermatogenic cells to high doses of adenovirus gene therapy vector does not result in germ cell transduction. Human Gene Therapy 11 1705-1712. (doi:10.1089/10430340050111359)

Hendrickx R, Stichling N, Koelen J, Kuryk L, Lipiec A \& Greber UF 2014 Innate immunity to adenovirus. Human Gene Therapy 25 265-284. (doi:10.1089/hum.2014.001)

Ho NR, Usmani AR, Yin Y, Ma L \& Conrad DF 2017 Multiplex shRNA screening of germ cell development by in vivo transfection of mouse testis. G3 7 247-255. (doi:10.1534/g3.116.036087)

Hooley RP, Paterson M, Brown P, Kerr K \& Saunders PT 2009 Intra-testicular injection of adenoviral constructs results in Sertoli cell-specific gene expression and disruption of the seminiferous epithelium. Reproduction 137 361-370. (doi:10.1530/REP-08-0247)

Hu GX, Lin H, Chen GR, Chen BB, Lian QQ, Hardy DO, Zirkin BR \& Ge RS 2010 Deletion of the Igf1 gene: suppressive effects on adult Leydig cell development. Journal of Andrology 31 379-387. (doi:10.2164/ jandrol.109.008680)

Ikawa M, Tergaonkar V, Ogura A, Ogonuki N, Inoue K \& Verma IM 2002 Restoration of spermatogenesis by lentiviral gene transfer: offspring from infertile mice. PNAS 99 7524-7529. (doi:10.1073/pnas.072207299)

Jackson NC, Jackson H, Shanks JH, Dixon JS \& Lendon RG 1986 Study using in-vivo binding of 125I-labelled hCG, light and electron microscopy of the repopulation of rat Leydig cells after destruction due to administration of ethylene-1,2-dimethanesulphonate. Journal of Reproduction and Fertility 76 1-10. (doi:10.1530/jrf.0.0760001)

Jimenez P, Saner K, Mayhew B \& Rainey WE 2003 GATA-6 is expressed in the human adrenal and regulates transcription of genes required for adrenal androgen biosynthesis. Endocrinology 144 4285-4288. (doi:10.1210/en.2003-0472)

Kanatsu-Shinohara M, Ogura A, Ikegawa M, Inoue K, Ogonuki N, Tashiro K, Toyokuni S, Honjo T \& Shinohara T 2002 Adenovirus-mediated gene delivery and in vitro microinsemination produce offspring from infertile male mice. PNAS 99 1383-1388. (doi:10.1073/pnas.022646399)

Kanatsu-Shinohara M, Toyokuni S \& Shinohara T 2004 Transgenic mice produced by retroviral transduction of male germ line stem cells in vivo. Biology of Reproduction 71 1202-1207. (doi:10.1095/ biolreprod.104.031294)

Kerr JB, Donachie K \& Rommerts FF 1985 Selective destruction and regeneration of rat Leydig cells in vivo. A new method for the study of seminiferous tubular-interstitial tissue interaction. Cell and Tissue Research 242 145-156. (doi:10.1007/BF00225571)

Ketola I, Rahman N, Toppari J, Bielinska M, Porter-Tinge SB, Tapanainen JS, Huhtaniemi IT, Wilson DB \& Heikinheimo M 1999 Expression and regulation of transcription factors GATA-4 and GATA-6 in developing mouse testis. Endocrinology 140 1470-1480. (doi:10.1210/ endo.140.3.6587)

Ketola I, Anttonen M, Vaskivuo T, Tapanainen JS, Toppari J \& Heikinheimo M 2002 Developmental expression and spermatogenic stage specificity of transcription factors GATA- 1 and GATA-4 and their cofactors FOG-1 and FOG-2 in the mouse testis. European Journal of Endocrinology $\mathbf{1 4 7}$ 397-406. (doi:10.1530/eje.0.1470397)

Kilcoyne KR, Smith LB, Atanassova N, Macpherson S, McKinnell C, van den Driesche S, Jobling MS, Chambers TJ, De Gendt K, Verhoeven G et al. 2014 Fetal programming of adult Leydig cell function by androgenic effects on stem/progenitor cells. PNAS 111 E1924-E1932. (doi:10.1073/ pnas.1320735111)

Kim JM, Luo L \& Zirkin BR 2000 Caspase-3 activation is required for Leydig cell apoptosis induced by ethane dimethanesulfonate. Endocrinology 141 1846-1853. (doi:10.1210/endo.141.5.7444)

Kim TS, Choi HS, Ryu BY, Gang GT, Kim SU, Koo DB, Kim JM, Han JH, Park CK, Her S \& Lee DS 2010 Real-time in vivo bioluminescence imaging of lentiviral vector-mediated gene transfer in mouse testis. Theriogenology 73 129-138. (doi:10.1016/j.theriogenology.2009.07.028)

King SR, Rommerts FF, Ford SL, Hutson JC, Orly J \& Stocco DM 1998 Ethane dimethane sulfonate and $\mathrm{NNN}^{\prime} \mathrm{N}^{\prime}$-tetrakis-(2-pyridylmethyl) ethylenediamine inhibit steroidogenic acute regulatory (StAR) protein expression in MA-10 Leydig cells and rat Sertoli cells. Endocrine Research 24 469-478. (doi:10.3109/07435809809032635)

Kojima Y, Sasaki S, Umemoto Y, Hashimoto Y, Hayashi Y \& Kohri K 2003 Effects of adenovirus mediated gene transfer to mouse testis in vivo on spermatogenesis and next generation. Journal of Urology $\mathbf{1 7 0}$ 2109-2114. (doi:10.1097/01.ju.0000092898.91658.08)

Krachulec J, Vetter M, Schrade A, Löbs AK, Bielinska M, Cochran R, Kyrönlahti A, Pihlajoki M, Parviainen H, Jay PY et al. 2012 GATA4 is a critical regulator of gonadectomy-induced adrenocortical tumorigenesis in mice. Endocrinology 153 2599-2611. (doi:10.1210/ en.2011-2135)

Kyrönlahti A, Euler R, Bielinska M, Schoeller EL, Moley KH, Toppari J, Heikinheimo M \& Wilson DB 2011 GATA4 regulates Sertoli cell function and fertility in adult male mice. Molecular and Cellular Endocrinology 333 85-95. (doi:10.1016/j.mce.2010.12.019)

LeCouter J, Lin R, Tejada M, Frantz G, Peale F, Hillan KJ \& Ferrara N 2003 The endocrine-gland-derived VEGF homologue Bv8 promotes angiogenesis in the testis: localization of Bv8 receptors to endothelial cells. PNAS 100 2685-2690. (doi:10.1073/pnas.0337667100)

Li T, Hu J, He GH, Li Y, Zhu CC, Hou WG, Zhang S, Li W, Zhang JS, Wang Z et al. 2012 Up-regulation of NDRG2 through nuclear factor-kappa B is required for Leydig cell apoptosis in both human and murine infertile testes. Biochimica et Biophysica Acta 1822 301-313. (doi:10.1016/j. bbadis.2011.11.013)

Lobo MV, Arenas MI, Huerta L, Sacristan S, Perez-Crespo M, GutierrezAdan A, Diaz-Gil JJ, Lasuncion MA \& Martin-Hidalgo A 2015 Liver growth factor induces testicular regeneration in EDS-treated rats and increases protein levels of class B scavenger receptors. American Journal of Physiology - Endocrinology and Metabolism 308 E111-E121. (doi:10.1152/ajpendo.00329.2014)

Machitani M, Sakurai F, Katayama K, Tachibana M, Suzuki T, Matsui H, YamaguchiT \& Mizuguchi H 2013 Improving adenovirus vector-mediated RNAi efficiency by lacking the expression of virus-associated RNAs. Virus Research 178 357-363. (doi:10.1016/j.virusres.2013.09.021)

Manuylov NL, Zhou B, Ma Q, Fox SC, Pu WT \& Tevosian SG 2011 Conditional ablation of Gata4 and Fog2 genes in mice reveals their 
distinct roles in mammalian sexual differentiation. Developmental Biology 353 229-241. (doi:10.1016/j.ydbio.2011.02.032)

Mazaud-Guittot S, Prud'homme B, Bouchard MF, Bergeron F, Daems C, Tevosian SG \& Viger RS 2014 GATA4 autoregulates its own expression in mouse gonadal cells via its distal $1 \mathrm{~b}$ promoter. Biology of Reproduction 9025.

Mitani K \& Kubo S 2002 Adenovirus as an integrating vector. Current Gene Therapy 2 135-144. (doi:10.2174/1566523024605591)

Molenaar R, de Rooij DG, Rommerts FF \& van der Molen HJ 1986 Repopulation of Leydig cells in mature rats after selective destruction of the existent Leydig cells with ethylene dimethane sulfonate is dependent on luteinizing hormone and not follicle-stimulating hormone. Endocrinology 118 2546-2554. (doi:10.1210/endo-118-6-2546)

O'Shaughnessy PJ \& Fowler PA 2011 Endocrinology of the mammalian fetal testis. Reproduction 141 37-46.

O'Shaughnessy PJ, Baker PJ, Heikkila M, Vainio S \& McMahon AP 2000 Localization of 17beta-hydroxysteroid dehydrogenase/17-ketosteroid reductase isoform expression in the developing mouse testisandrostenedione is the major androgen secreted by fetal/neonatal leydig cells. Endocrinology 141 2631-2637. (doi:10.1210/en.141.7.2631)

O'Shaughnessy PJ, Willerton L \& Baker PJ 2002 Changes in Leydig cell gene expression during development in the mouse. Biology of Reproduction 66 966-975. (doi:10.1095/biolreprod66.4.966)

O'Shaughnessy PJ, Morris ID \& Baker PJ 2008 Leydig cell re-generation and expression of cell signaling molecules in the germ cell-free testis. Reproduction 135 851-858. (doi:10.1530/rep-07-0529)

O'Shaughnessy PJ, Monteiro A, Fowler PA \& Morris ID 2014 Identification of Leydig cell-specific mRNA transcripts in the adult rat testis. Reproduction 147 671-682. (doi:10.1530/rep-13-0603)

Oka T, Maillet M, Watt AJ, Schwartz RJ, Aronow BJ, Duncan SA \& Molkentin JD 2006 Cardiac-specific deletion of Gata4 reveals its requirement for hypertrophy, compensation, and myocyte viability. Circulation Research 98 837-845. (doi:10.1161/01.RES.0000215985.18538.c4)

Padua MB, Jiang T, Morse DA, Fox SC, Hatch HM \& Tevosian SG 2015 Combined loss of the GATA4 and GATA6 transcription factors in male mice disrupts testicular development and confers adrenal-like function in the testes. Endocrinology 156 1873-1886. (doi:10.1210/en. 2014-1907)

Pihlajoki M, Gretzinger E, Cochran R, Kyrönlahti A, Schrade A, Hiller T, Sullivan L, Shoykhet M, Schoeller EL, Brooks MD et al. 2013 Conditional mutagenesis of Gata6 in SF1-positive cells causes gonadallike differentiation in the adrenal cortex of mice. Endocrinology 154 1754-1767. (doi:10.1210/en.2012-1892)

Pihlajoki M, Färkkilä A, Soini T, Heikinheimo M \& Wilson DB 2016 GATA factors in endocrine neoplasia. Molecular and Cellular Endocrinology 421 2-17. (doi:10.1016/j.mce.2015.05.027)

Qamar I, Park E, Gong EY, Lee HI \& Lee K 2009 ARR19 (androgen receptor corepressor of $19 \mathrm{kDa}$ ), an antisteroidogenic factor, is regulated by GATA-1 in testicular Leydig cells. Journal of Biological Chemistry 284 18021-18032. (doi:10.1074/jbc.M900896200)

Qamar I, Ahmad MF \& Narayanasamy A 2015 A time-course study of long term over-expression of ARR19 in mice. Science Reports 513014. (doi:10.1038/srep13014)

Rahman NA, Kiiveri S, Rivero-Muller A, Levallet J, Vierre S, Kero J, Wilson DB, Heikinheimo M \& Huhtaniemi I 2004 Adrenocortical tumorigenesis in transgenic mice expressing the inhibin alpha-subunit promoter/SV40 virus T-antigen transgene: relationship between ectopic expression of luteinizing hormone receptor and transcription factor GATA-4. Molecular Endocrinology 18 2553-2569. (doi:10.1210/me.2002-0282)

Röhrig T, Pihlajoki M, Ziegler R, Cochran RS, Schrade A, Schillebeeckx M, Mitra RD, Heikinheimo M \& Wilson DB 2015 Toying with fate: redirecting the differentiation of adrenocortical progenitor cells into gonadal-like tissue. Molecular and Cellular Endocrinology 408 165-177. (doi:10.1016/j.mce.2014.12.003)

Rudigier LJ, Dame C, Scholz H \& Kirschner KM 2017 Ex vivo cultures combined with vivo-morpholino induced gene knockdown provide a system to assess the role of WT1 and GATA4 during gonad differentiation. PLOS ONE 12 e0176296. (doi:10.1371/journal.pone.0176296)

Salva A, Hardy MP, Wu XF, Sottas CM, MacLaughlin DT, Donahoe PK \& Lee MM 2004 Müllerian-inhibiting substance inhibits rat Leydig cell regeneration after ethylene dimethanesulphonate ablation. Biology of Reproduction 70 600-607. (doi:10.1095/biolreprod.103.021550)
Schrade A, Kyrönlahti A, Akinrinade O, Pihlajoki M, Fischer S, Rodriguez VM, Otte K, Velagapudi V, Toppari J, Wilson DB \& Heikinheimo M 2016 GATA4 regulates blood-testis barrier function and lactate metabolism in mouse Sertoli cells. Endocrinology 157 2416-2431. (doi:10.1210/ en.2015-1927)

Schrade A, Kyrönlahti A, Akinrinade O, Pihlajoki M, Häkkinen M, Fischer S, Alastalo TP, Velagapudi V, Toppari J, Wilson DB \& Heikinheimo M 2015 GATA4 is a key regulator of steroidogenesis and glycolysis in mouse Leydig cells. Endocrinology 156 1860-1872. (doi:10.1210/ en.2014-1931)

Sher N, Yivgi-Ohana N \& Orly J 2007 Transcriptional regulation of the cholesterol side chain cleavage cytochrome P450 gene (CYP11A1) revisited: binding of GATA, cyclic adenosine 3',5'-monophosphate response element-binding protein and activating protein (AP)-1 proteins to a distal novel cluster of cis-regulatory elements potentiates AP-2 and steroidogenic factor-1-dependent gene expression in the rodent placenta and ovary. Molecular Endocrinology 21 948-962. (doi:10.1210/ me.2006-0226)

Shima Y \& Morohashi KI 2017 Leydig progenitor cells in fetal testis. Molecular and Cellular Endocrinology 445 55-64. (doi:10.1016/j. mce.2016.12.006)

Shima Y, Miyabayashi K, Haraguchi S, Arakawa T, Otake H, Baba T, Matsuzaki S, Shishido Y, Akiyama H, Tachibana T et al. 2013 Contribution of Leydig and Sertoli cells to testosterone production in mouse fetal testes. Molecular Endocrinology 27 63-73. (doi:10.1210/ me.2012-1256)

Shiraishi K \& Ascoli M 2007 Lutropin/choriogonadotropin stimulate the proliferation of primary cultures of rat Leydig cells through a pathway that involves activation of the extracellularly regulated kinase $1 / 2$ cascade. Endocrinology 148 3214-3225. (doi:10.1210/en.2007-0160)

Smith L 2011 Good planning and serendipity: exploiting the Cre/Lox system in the testis. Reproduction 141 151-161. (doi:10.1530/REP10-0404)

Smith LB, O'Shaughnessy PJ \& Rebourcet D 2015 Cell-specific ablation in the testis: what have we learned? Andrology 3 1035-1049. (doi:10.1111/ andr.12107)

Sodhi CP, Li J \& Duncan SA 2006 Generation of mice harbouring a conditional loss-of-function allele of Gata6. BMC Developmental Biology 6 19. (doi:10.1186/1471-213X-6-19)

Sriraman V, Sairam MR \& Rao AJ 2003 Evaluation of relative roles of LH and FSH in regulation of differentiation of Leydig cells using an ethane 1,2-dimethylsulfonate-treated adult rat model. Journal of Endocrinology 176 151-161. (doi:10.1677/joe.0.1760151)

Taylor MF, Woolveridge I, Metcalfe AD, Streuli CH, Hickman JA \& Morris ID 1998 Leydig cell apoptosis in the rat testes after administration of the cytotoxin ethane dimethanesulphonate: role of the Bcl-2 family members. Journal of Endocrinology 157 317-326. (doi:10.1677/ joe.0.1570317)

Taylor MF, de Boer-Brouwer M, Woolveridge I, Teerds KJ \& Morris ID 1999 Leydig cell apoptosis after the administration of ethane dimethanesulfonate to the adult male rat is a Fas-mediated process. Endocrinology 140 3797-3804. (doi:10.1210/endo.140.8.6919)

Teerds KJ \& Huhtaniemi IT 2015 Morphological and functional maturation of Leydig cells: from rodent models to primates. Human Reproduction Update 21 310-328. (doi:10.1093/humupd/dmv008)

Teerds KJ, de Rooij DG, Rommerts FF, van den Hurk R \& Wensing CJ 1989 Proliferation and differentiation of possible Leydig cell precursors after destruction of the existing Leydig cells with ethane dimethyl sulphonate: the role of $\mathrm{LH} /$ human chorionic gonadotrophin. Journal of Endocrinology 122 689-696. (doi:10.1677/joe.0.1220689)

Tevosian S 2014 Transgenic mouse models in the study of reproduction: insight into GATA protein function. Reproduction 148 R1-R14. (doi:10.1530/REP-14-0086)

Tevosian SG, Jimenez E, Hatch HM, Jiang T, Morse DA, Fox SC \& Padua MB 2015 Adrenal development in mice requires GATA4 and GATA6 transcription factors. Endocrinology 156 2503-2517. (doi:10.1210/ en.2014-1815)

Tremblay JJ 2015 Molecular regulation of steroidogenesis in endocrine Leydig cells. Steroids 103 3-10. (doi:10.1016/j.steroids.2015.08.001)

Tremblay JJ \& Viger RS 2001 GATA factors differentially activate multiple gonadal promoters through conserved GATA regulatory elements. Endocrinology 142 977-986. (doi:10.1210/endo.142.3.7995) 
Tsuzuki S, Tachibana M, Hemmi M, Yamaguchi T, Shoji M, Sakurai F, Kobiyama K, Kawabata K, Ishii KJ, Akira S et al. 2016 TANK-binding kinase 1-dependent or -independent signaling elicits the celltype-specific innate immune responses induced by the adenovirus vector. International Immunology 28 105-115. (doi:10.1093/intimm/ dxv058)

Viger RS, Mertineit C, Trasler JM \& Nemer M 1998 Transcription factor GATA-4 is expressed in a sexually dimorphic pattern during mouse gonadal development and is a potent activator of the Müllerian inhibiting substance promoter. Development 125 2665-2755.

Virtanen HE \& Toppari J 2014 Embryology and physiology of testicular development and descent. Pediatric Endocrinology Reviews 11 (Supplement 2) 206-213.

Watt AJ, Battle MA, Li J \& Duncan SA 2004 GATA4 is essential for formation of the proepicardium and regulates cardiogenesis. PNAS 101 12573-12578. (doi:10.1073/pnas.0400752101)

Wen Q, Cheng CY \& Liu YX 2016 Development, function and fate of fetal Leydig cells. Seminars in Cell and Developmental Biology 59 89-98. (doi:10.1016/j.semcdb.2016.03.003)

Wu HS, Lin HT, Wang CK, Chiang YF, Chu HP \& Hu MC 2007 Human CYP11A1 promoter drives Cre recombinase expression in the brain in addition to adrenals and gonads. Genesis 45 59-65. (doi:10.1002/ dvg.20266)

Yan W, Kero J, Huhtaniemi I \& Toppari J 2000 Stem cell factor functions as a survival factor for mature Leydig cells and a growth factor for precursor Leydig cells after ethylene dimethane sulfonate treatment: implication of a role of the stem cell factor/c-kit system in Leydig cell development. Developmental Biology 227 169-182. (doi:10.1006/ dbio.2000.9885)

Yang Y, Nunes FA, Berencsi K, Furth EE, Gonczol E \& Wilson JM 1994 Cellular immunity to viral antigens limits E1-deleted adenoviruses for gene therapy. PNAS 91 4407-4411. (doi:10.1073/pnas.91.10.4407)

Yang Y, Li Z, Wu X, Chen H, Xu W, Xiang Q, Zhang Q, Chen J, Ge RS, Su Z et al. 2017 Direct reprogramming of mouse fibroblasts toward Leydig-like cells by defined factors. Stem Cell Reports 8 39-53. (doi:10.1016/j.stemcr.2016.11.010)

Zhang L, Wang H, Yang Y, Liu H, Zhang Q, Xiang Q, Ge R, Su Z \& Huang Y 2013 NGF induces adult stem Leydig cells to proliferate and differentiate during Leydig cell regeneration. Biochemical and Biophysical Research Communications 436 300-305. (doi:10.1016/j.bbrc.2013.05.098)

Zhang YF, Yuan KM, Liang Y, Chu YH, Lian QQ, Ge YF, Zhen W, Sottas CM, Su ZJ \& Ge RS 2015 Alterations of gene profiles in Leydig-cell-regenerating adult rat testis after ethane dimethane sulfonate-treatment. Asian Journal of Andrology 17 253-260. (doi:10.4103/1008-682X.136447)

Received 22 May 2017

First decision 13 June 2017

Revised manuscript received 9 July 2017

Accepted 14 July 2017 